\title{
Self-Directed Learning as a Practice of Workplace Learning: Interpretative Repertoires of Self-Directed Learning in ICT Work
}

\author{
Soila Lemmetty ${ }^{1}$ (1) $\cdot$ Kaija Collin ${ }^{1}$
}

Received: 17 May 2018 / Accepted: 15 July 2019 / Published online: 27 July 2019

(C) The Author(s) 2019

\begin{abstract}
Changing technologies and competition in the field of information and communication technology (ICT) are challenging the learning of individual workers and teams alongside and through work. Organisations call for employees' autonomy and self-directedness executed by agile operations and low hierarchies, where learning is also increasingly the responsibility of the individuals and teams themselves and occurs in practice without strong control of the organisation. Therefore, the multidimensional concept of selfdirected learning becomes essential in the context of learning at work. In this study, we examine how employees in the ICT sector describe self-directed learning practices in the context of workplace learning. Our data consist of interviews with ICT employees in two organisations, which undergo an applied discourse analysis. The workers talked about self-directed learning as an obliged, creativity-enhanced as well as flexible and fast-paced practice. Self-directed learning was also described as a practice tied to work itself. The paper concludes with a discussion on how these partly conflicting discourses about selfdirected learning practice in work could be considered in practices related to enhancing such learning in the ICT field. Suggestions for future investigations are also presented.
\end{abstract}

Keywords Workplace learning · Self-directed learning · Discourse analysis · Interpretative repertoires $\cdot$ ICT organisation

\section{Introduction}

Technological changes in the field of information and communication technology (ICT) are challenging workers to continuously learn and develop professionally (Ha

Soila Lemmetty

soila.j.lemmetty@jyu.fi

1 Department of Education, University of Jyväskylä, Alvar Aallon katu 9 /, P.O. Box 25 40014, Jyväskylä, Finland 
2008). According to the study of Yeo (2008), 80\% of learning at work occurs informally and is self-directed in nature. Thus, responsibility to learn lies on the individual or teams themselves. Workplace learning does not only mean formal training, but it should also carry a focus on the activities in the work (Billett 2014), where learning has shown to be practice based, work related and self-directed. Studies also have shown that learning embedded in work practices can improve both individual employees', teams' and organisations' competitiveness and is an important means for continuing competence development (Manuti et al. 2015).

Organisations have begun to transfer power from organisations to individuals for more flexible, faster and effective operations (Rigby and Ryan 2018). This has become possible by lowering organisational structures and creating self-directed teams that can respond to individual projects (Holbeche 2015; Lee and Edmondson 2017; Moe et al. 2008). At the same time, responsibility for learning at work has also increasingly moved to the individuals and teams themselves (Ellinger 2004; Friedman 2005). As coping on the job has become increasingly the responsibility of workers themselves and work itself more fast-paced (Harteis 2017), learning practices promoting professionals' competence development are changing as well. The nature of these self-directed practices must also be considered in research (Harteis 2017). Therefore, the framework of self-directed learning (SDL) practice (e.g., Knowles 1975) would seem to be a topical starting point when considering the practice of learning at work in these organisations underlining employees' and teams' self-directedness. Although SDL has long been studied in adult education and andragogy, the need to examine and study the multidimensional nature of SDL in the context of workplace learning has been highlighted (cf. Gu 2016; Ellinger 2004; Rana et al. 2016).

The participants of the current study are employees working in the ICT sector; this sector is one of the drivers of current economic growth and increased employability. ICT professionals are expected to produce high-quality products and services for their customers, and learning and creativity are promoted as responses to the increasing demands of their working life (Ulrich and Mengiste 2014). Because of the innovative, artistic and fast-paced nature of ICT work based on continuous problem solving and development (Bauer et al. 2012), SDL is needed to answer to the requirements of competence development through work practices.

Although, there has been earlier research on learning practices at work, some researchers have argued that studies on the topic have been too theoretical and have lacked empirical evidence (Lee and Roth 2006). Some of the empirical studies have been conducted as ethnographic case studies (e.g., Valleala et al. 2015) or primarily based on interviews and surveys (e.g., Milligan et al. 2015; Vanthournout et al. 2014). However, there is a need also for in-depth tools to understand learning and SDL as phenomena in the context of work and to determine the learning methods or resources employees use to achieve their learning goals (Pintrich 2004; Ha 2008; Loftus and Higgs 2010). Discourse analysis and its instruments have been described as a useful method for generating information about different dimensions and descriptions of multidimensional phenomena (Wetherell and Potter 1988), such as learning. However, in the field of workplace learning there is a lack of studies utilising discourse analytical methods (cf. Lee and Roth 2006; Boud and Solomon 2003.) For these reasons, in this study, the nature of practice of self-directed learning is examined with the help of discourse analysis to better understand employees' descriptions and multiple 
interpretations of SDL practice at work. Thus, in the current study, we ask the following: How do employees of ICT organisations describe the practice of SDL in the context of workplace learning?

\section{Workplace Learning as Practices and SDL at Work}

\section{Workplace Learning Practices Producing Employees' Competencies and Organisational Goals}

The ability of organisations to innovate and be successful in the labour market depends on employees' continuous learning (Davis and Daley 2008). Over the past couple of decades, learning at work has strongly been approached as formal training, but also as work related and practice based (Billett 2001, 2014; Collin 2006). Research in the field has also focused on the development of employees' skills and competencies while working (Noe and Ellingson 2017; Paloniemi 2006; Collin 2006). Although there is growing interest in understanding different 'learning through work' activities, as well as interaction and participation (Billett 2014), the perspective of individual autonomy in learning has also increased (e.g., Ellinger 2004; Karakas and Manisaligil 2012; Noe and Ellingson 2017). Thus, learning at work can be seen as different practices that are emerging when working. 'Practice' generally refers to the routines, norms and beliefs in which everyday activities are embedded (Bourdieu 1977, 1990). In the context of workplace learning, practice is a system of activities in witch knowledge is not separate from doing (Gherardi 2000). Workplace learning practices can appear both as individual (e.g., autonomous problem solving) (Noe et al. 2014) or shared and collective-level (e.g., interaction) activities (Collin 2006; Billett 2001).

According to Matthews (1999), all learning at work should aim to and promote sustainable development of both the individual and organisation. However, learning at work has been merely described as a way to develop individuals' own competencies (Paloniemi 2006). The concept of competencies has been used to describe the skills and abilities of individuals, whereas, for example, the term 'knowledge' has been utilised in both organisational- and individual-level descriptions (Lehner and Sundby 2017). The definition of a competence is thus ambiguous, but it is often described as an individual's ability to perform the tasks assigned to him or her (Streumer and Björkvist 1998). Because the current study specifically examines the practice of learning at work as an activity that develops the competencies of the individual (Matthews 1999), we use the term 'competence' to describe an individual's skills, abilities and expertise (cf. Paloniemi 2006). The competencies of ICT professionals include programming languages and software development tools and the skills to deliver technical support to users. Workplace learning, especially self-directed practices (e.g., reading professional literature), but also through participation in communities and through working on projects, has been seen as some of the prerequisites for developing such skills (Edwards 2010; Ha 2015).

\section{SDL as a Practice of Workplace Learning}

Most of learning at work emerges informally and in a self-directed manner (Yeo 2008). Gerber et al. (1995) found that typical workplace learning activities, such as learning 
from mistakes, self-managed observation, training others and learning through interaction, were SDL activities because employees emphasised the responsibility of individuals and groups when speaking about their learning. Ellinger (2004) also underlined learning at work as being inherently self-directed because learning is nowadays seen as an essential part of work. In addition, the responsibility for learning has shifted to the individuals and teams themselves. In the workplace, there is an increased interest in transferring power from institutions to individuals (Rigby and Ryan 2018) because individual self-directed action seems to be the key for enabling both continuous competence development and creativity (Gijbels et al. 2012). Thus, the practice of SDL is recognized as a topical and important part in the field of workplace learning research and practice, especially in case where aim of the learning is to grow employees' competency.

The concept of self-directedness has been emphasised since the 1920s, originally referring to the natural need of adults to act in a self-directed way (Lindeman 1926). The idea of self-directedness in learning emerged from andragogy, according to which adult learners are independently capable of elaborating on their learning goals, have a lot of experience as learning resources, can apply situation sensitivity based on their experiences and are motivated to learn through internal factors instead of external ones (Knowles 1975). The framework of SDL has also been brought into the context of workplace learning (Candy 1991; Artis and Harris 2007; Knowles et al. 2012), which has recently been accompanied by the concepts of autonomous learning (Noe and Ellingson 2017), self-learning (Ha 2008) and self-regulated learning (SRL) (Pintrich 2004). However, there are differences in the background of the concepts, but all of them share the idea of the responsibility of the actors in relation to their learning activities and the individual's awareness of his or her own learning needs and opportunities (London and Mone 1999). However, SDL is a broader concept and unlike SRL, it takes into account not only the characteristics of the individual, but also the importance of learning environment and collaboration (Loyens et al. 2008). In SDL autonomy is not a necessary concept for learning. Instead, enabling autonomy depends on how much responsibility the individual has regarding the different decisions in learning (Nunan and Lamb 1996). No one can always be completely autonomous (Merriam and Caffarella 1999). Brookfield (1993) described the SDL as a practice in which the individual takes responsibility for a situation either with or without others' help. Thus, self-directedness does not directly translate into a completely autonomous individual learning activity: SDL can also occur collectively and it can also be influenced by the organization in the context of work (Maehl 2000; Candy 1991). Therefore, the concept of self-directedness should be criticised for giving an image of a one-sided and autonomous activity (Candy 1991), even though studies have found that SDL is not realised in such a radical way that no other people would have any effect on learning (Loyens et al. 2008.)

SDL is described as a goal itself or a skill to be developed (e.g., Brockett and Hiemstra 1991; Knowles 1975) and as an individual feature (e.g., Lindeman 1926; Guglielmino 2008). However, the broadest framework for SDL is based on the idea of SDL as a practice (Khiat 2017; Caffarella 1993; Knowles et al. 2012). In his research, Though (1971) explored nonformal adult learning practices that he identified as selfdirected because these practices were designed, embedded and controlled by the adults themselves. This practice-based view is also the starting point for a number of very 
linear process descriptions of SDL. Common to all these descriptions is that a learner who is employing SDL can manage the learning process from the beginning to the end (e.g., Knowles 1975; Brockett and Hiemstra 1991; Brookfield 1986, 1993; Pintrich 2004). Therefore, the individual is responsible for the setting, design, implementation and evaluation of learning goals (Merriam and Caffarella 1999; Merriam 2001). In this sense, SDL at work can take place in a variety of contexts: formal, informal, online or social interaction (Noe et al. 2014). In the current study, we approach SDL as one of many workplace learning practices. In this practice, individuals or teams take responsibility (cf. Merriam and Caffarella 1999; Brookfield 1993; Though 1971) for their own 'on-the-job' or 'through work' workplace learning (Billett 2014). Consequently, the development of one's own competencies also helps in achieving an organisation's developmental goals (Matthews 1999).

\section{The Importance of SDL in the ICT Sector}

In ICT sector, flexible work guides employees to commit to working and learning in a self-directed manner (e.g., Heinz 2010). This type of development entails reading and obtaining information from various sources (e.g., the Internet), becoming familiar with programming languages and tools and participating in projects (Edwards 2010; Ha 2008, 2015). Learning in ICT work is supported by challenging and interesting tasks and collaboration, while routine-like tasks, the need to rush, old technologies, the boundaries between professional groups and the expectations of short-term work effectiveness constrain learning and creativity (Vähäsantanen and Eteläpelto 2017). In the field of software engineering (cf. Collin 2006; Havnes and Smeby 2014; Nerland 2008), work is highly problem driven, and employees are involved in short-term loops of problem-driven learning (Hirschmann and Mulder 2018). These kind of workplaces have proven they offer a large variety of both individual- and collegial-based resources for learning (Billett 2001; Schürmann and Beausaert 2016). Despite the positive meanings of learning described in some previous studies, the negotiations that take place when a learner discovers his or her identity might be demanding for this specific group of employees (Ha 2015; Kirpal 2009; Soreide 2016) because employees in ICT organisations are immersed in a culture that requires ongoing learning driven by both the employers' and employees' expectations (Fuller and Unwin 2010; Riddell et al. 2009). Here, learning is approached as a necessary function of the organisation (Scheeres et al. 2010; Ha 2015).

In modern times, especially in ICT organisations, organisational structures have changed from hierarchical and managerial-oriented structures to increasingly focusing on the autonomy of employees and self-directedness (Bauer et al. 2012; Cerasoli et al. 2018). These kinds of organisations have been called as 'agile', 'fast-paced', 'lowhierarchy' and 'self-organised' (Lee and Edmondson 2017; Holbeche 2015; Salovaara and Bathurst 2018). In practice, this means, for example, that the teams are so-called 'self-directed teams' that carry the responsibility for the entire project. Inside the team, the tasks are clearly divided to be carried out by different people whose handle these tasks responsibly (Moe et al. 2008). We do not know exactly how learning and competency development in this kind of work and structure should be promoted or supervised (Bauer et al. 2012). Therefore, it is possible to assume that the responsibility for learning within this kind of work will increasingly be placed on the individuals and 
teams themselves. However, there is a lack of research on self-directed practices in organisations and the nature of learning in these organisations (Lee and Edmondson 2017). Consequently, looking at SDL in modern self-organised ICT organisations is very topical.

In this study, we approach SDL as a practice of workplace learning where individuals and groups take responsibility for their learning in different situations, aiming to develop their own competency. Emphasizing the practice of SDL in the context of work is important because of the complexity and scarce research on the concept, but also from the point of view of the culture and structures that emphasize the self-directedness in organizations. Self-directed learning will be an important part of employee' learning in the future as both learning needs and employee responsibility increase (Noe et al. 2014). According to Pintrich (2004), SDL should be explored through methodology that highlights the diversity of the phenomenon at hand. Consequently, we used a discourse analysis, obviously suitable method aiming to comprehensive understanding of this multi-faceted phenomenon (Wetherell and Potter 1988).

\section{Aim and Research Questions}

The aim of the current study is to investigate how personnel in ICT organisations describe SDL practice at work. Our aim is to understand the interviewed employees' views, accounts and multiple interpretations of SDL practice in the context of workplace learning through co-constructed speech and to gain new knowledge about the interdimensional nature of SDL (cf. Pintrich 2004). Thus, in the present study, which is based on discourse analysis, we ask the following: How do employees of IT organisations describe the practice of SDL in the context of workplace learning? More specifically, we ask the following: What kinds of interpretative repertoires of SDL practice do employees in the ICT sector produce in their speech? In addition, the purpose is to find out how the interviewees position themselves, other members of the work community and the organisation in each repertoire, what contexts of the speech can be seen and what the employees want to say through their ways of speaking.

\section{Methodology}

The current study is based on social constructivism, which states that knowledge, reality and its structures and phenomena are constructed in social and linguistic interactions (Gergen 1999). The construction of knowledge is examined at the social community and cultural levels, ignoring individual psychological structures and processes (Gergen 1999). From a social constructivist point of view - and in the field of workplace learning research - it is crucial to explore the modes of speech and discourses that people use to construct their views (Tynjälä 2013; Burr 1995). The current study focuses on discourses (i.e., the speech of the target organisations' personnel) and ignores cognitive functions, schemas and phrase linguistics (Potter and Wetherell 1987; van Dijk 1998). Our purpose is to discover what kinds of different ways of talking about SDL practice are used, thereby increasing our understanding of the different aspects and nature of SDL. Therefore, the current research employs a 
discourse study (Stubbs 1983; Nunan 1993; Silverman 1997; Edley 2001; Potter and Wetherell 1987). An applied discourse study focuses on the actual research of cultural actors, and a discourse is seen as the result or outcome of an actor's active social interaction. In this kind of activity, a discourse is defined as the sum of commonly agreed-upon views on the nature of reality, and these views are true in a specific environment when experienced and presented by certain people (van Dijk 1998).

\section{Data}

The data of the current study were gathered together with the data collection of the HeRMo (Ethical Human Resource Management and Leadership Practices Promoting Creative Activity in Finnish Growth Companies) research project, which looks at phenomena of leadership, creativity and learning at work. The participants in the current study included one large (130 employees) and one small (30 employees) ICT organisation. These organisations were chosen because of their low-hierarchy, agility-focused and selfdirected practices - features that are generally present in the ICT sector (Salovaara and Bathurst 2018) - and because of the central meaning of learning for ICT work in the future (Martins and Terblanche 2003). Organisation A is an ICT company with more than 100 employees. The company has grown extensively in recent years. The company's main office is in central Finland, but it also has four smaller offices across the country. Its organisational structure consists of departments that are based on work tasks: software development, sales, customer service and IT support. Smaller teams within these departments are responsible for ongoing projects. The company has been striving for a lowhierarchy, minimal bureaucracy that places the responsibility for work on the employees. The departmental teams work in a self-directed manner; a team and individuals are responsible for a project, directly connecting with customers and ensuring agreement among the team members regarding the project's content and responsibilities. The leadership goal within these teams is to eliminate obstacles and factors that disturb everyday work. Software teams have project leaders who are responsible for supporting and guiding everyday work. Project leaders also work with customers. In addition, software developers have a human resources (HR) manager with whom they can discuss employment issues. Salespersons and IT support providers have HR managers as well. Organisation $B$ is a small ICT company operating in Finland and employs fewer than 30 people. It has one main office and one other office in Finland. Additionally, some of the employees work at customer offices on customers' projects. This company offers software design and consulting services. The employees work as software designers, software developers and consultants. The company also employs a chief executive officer, HR manager, marketing persons and salespersons. The company has been striving for a low-hierarchy, minimal bureaucracy that places the responsibility for work on the employees. Every employee has a superior, and every project has a project leader who is responsible for everyday work and support.

Research (e.g its aims, themes, data collection, progression, anonymity) was introduced to employees via handouts and e-mail bulletins provided by the researchers and the organizations' managers. The researchers visited the participating organizations several times before starting the data collection, familiarizing themselves with the organizations by following the personnel's daily activities. Interviewees were randomly selected, however, representing different job titles. Participation was voluntary and every individual was 
requested to give his/her consent to use the interview material for research purposes. The data consisted of 23 interviews (see Table 1) collected in 2017. In the interviews, the descriptions of the interviewees' learning were addressed. At the beginning of the interviews, the participants were again told about the study in detail (subject of the research, the goal, the schedule and what for and how the data will be used). Privacy practices and data retention principles were also discussed. The target organisations and the individual respondents were anonymised so that it is not possible to identify the respondents in the research reports. All of the described actions also ensured the credibility and dependability of this research (see Shenton 2004; Elo et al. 2014), and helped the researchers to follow ethical guidelines.

The interviews were conducted as individual, semistructured, thematic interviews, emphasising a conversional style between the interviewer and interviewee. The overall themes discussed touched on leadership and managerial work, injustice, creativity and creative activity, workplace learning and competency development. In the present study, the interview questions that were part of the theme 'workplace learning and competence development' were used primarily, such as for the following interview questions: 'What do you think about learning at work?'; 'How do you learn or develop your competencies at

Table 1 Interviewees of the study

\begin{tabular}{lll}
\hline Id. number & Job title & Organization \\
\hline 1 & Consultant & B \\
2 & Consultant & B \\
3 & Consultant & B \\
4 & IT expert / Marketing developer & A \\
5 & IT expert / Sales person & A \\
6 & IT expert / Sales person & A \\
7 & IT expert / IT support & A \\
8 & Software developer & A \\
9 & Software developer & A \\
10 & Software developer & A \\
11 & Software developer & A \\
12 & Software developer & A \\
13 & Software developer & A \\
14 & Software developer & A \\
15 & Software developer & B \\
16 & Software developer & B \\
17 & Software developer & B \\
18 & Software developer & B \\
19 & Software developer, project leader & A \\
20 & Software developer, project leader & A \\
21 & Software developer, project leader & A \\
22 & Software developer, project leader & B \\
23 & Software developer, project leader & \\
\hline & & \\
\hline & & \\
\hline
\end{tabular}


work?'; What do you mean by learning in your job?'; and 'How does your organization support your workplace learning or competency development?' The questions varied depending on the interview situation and the interviewee. Advisory questions were utilised if the employee found it difficult to spontaneously speak about the theme at hand.

In line with the discourse study, speech stored in text format (Stubbs 1983; Nunan 1993) constitute the data of the current study. The interviewees were software developers and salespersons performing client support or other duties in the ICT sector. The participants did not work in formal managerial positions, but some had other expert roles in the organisations (e.g., project leader). Before starting the analysis, all the interviews were transcribed. We did not take note of or transcribe the sighs, breaks or silent moments during the speech because the data consisted of interviews instead of, for example, everyday discussions and because this level of verbatim transcription was not necessary for the purposes of the current study (Stubbs 1983; Nunan 1993). After transcription, the data were thoroughly read to establish an overview of the interviews. Altogether, 71 pages $(30,871$ words) of learning-related speech were found. This pretreated material was used as the data for the discourse analysis.

\title{
Analysis
}

In the current study, discourse analysis methods, tools and instruments were applied (e.g., Silverman 1997; Taylor 2001). The aim of the analysis was to find different kinds of discourses or ways of talking (i.e., speech) that ignore cognitive functions, schemas and phrase linguistics (Potter and Wetherell 1987). First, we searched for all the fragments in which employees are talking about the practice of SDL. The following quote serves as an example of a fragment of interview material that was interpreted as describing the 'practice of SDL in the context of workplace learning':

\section{Interviewer: Are there any opportunities for learning, here, at work?}

\begin{abstract}
Software developer (8): The most obvious opportunity is that if a customer comes up with a request that 'we would like this feature in this system', when you start to think either alone or with a group, that if it is possible to do it at all then you may need to check things using Google and see if anyone else has done it before, and usually, there is a blog or something similar that somebody has done. You read it and take the things that you can apply or use, and this is how the knowledge and competency are accumulating.
\end{abstract}

We began the analysis by identifying fragments that have the kinds of meanings, entities and sets of meanings for self-directed learning. In accordance with a discourse analysis, we termed these sets of meanings interpretative repertoires (Edley 2001; Potter and Wetherell 1987; Wetherell 1998). The analysis focused on the use of speech and language and on how the interviewees constructed the reality of SDL in the context of workplace learning in ICT organisations. Attention was paid to the various ways of talking about SDL and the meanings, adjectives, depictions, metaphors or examples given by the interviewees when speaking about SDL in the context of work. The definition of the variability of speech is essential when forming interpretative repertoires; it means that speeches may include many ways of talking about the same thing (Wetherell and Potter 
1992). A speech is not usually dominated by a single interpretative repertoire; there can be several competing or collaborating repertoires in speeches (Wetherell and Potter 1988). Therefore, a discourse analysis is suitable for the study of SDL, where the aim is to study the interdimensional nature of the phenomenon (cf. Pintrich 2004). Utilising this method, learning speech acts were examined in detail - one by one - to reveal similarities. In this phase of the analysis, we paid attention to different kinds of metaphors, examples and descriptions in the interviewees' speech. We noticed various types of content, but speech about self-learning was constructed in a very similar manner throughout the data. As a result, four interpretative repertoires were revealed.

To better understand these interpretative repertoires, we used three different discourse analysis instruments: 1) function, 2) context and 3) subject position. In the current study, function means the purpose of speech (i.e., why the interviewee is talking in this way). To better understand the meaning of speech and the function of learning speech, we also had to examine the context (i.e., time and space) in the repertoires. Contexts are discovered by examining the situations or settings in which the speeches attached to each repertoire take place. The contexts create structures and positions to which the actor or speaker relates him- or herself or others (Silverman 1997). For this reason, we also examined how the actor or speaker positions him- or herself in each repertoire, as well as individual commitments, responsibilities, rights or statuses. To gain information of the collective nature of SDL practice, we also looked at the interviewees' talk about how they position others (colleagues, supervisors) in each interpretation repertoire. In addition, we wanted to explore from what kinds of positions the employees describe the organizations, and thus find out how the organizations 'practices and culture appear in the employees' talk (Edley 2001). Examples of carrying out the analysis are summarised in Appendix 1.

\section{Findings}

In the current study, we found four interpretative repertoires the interviewees used when talking about SDL practice in the context of workplace learning. These repertoires describe SDL practice and its function, context and subject positions in very different manners. Example extracts from the data can also be found in Appendix 1.

Next, we present these four different interpretative repertoires of SDL practice we discovered during the current study. We also present the functions, contexts and subject positions (individual, others and organisation) of each repertoire. Table 2 summarises the interpretative repertoires of SDL.

\section{Obliged Practice}

In this interpretative repertoire, SDL was described as a requirement and area of work that one must master to perform the work in the first place. Practice was described as constrained, indispensable, challenging and problematic, and it exclusively manifested as a stressful and burdening phenomenon that one could not always find time for, even though he or she was obliged to do so. Through their speeches, the interviewed personnel expressed a very critical and negative picture of SDL. The function of the speech could, therefore, reveal a critical perspective of SDL practice, one that is obliged in nature and obligated by external factors. Employees spoke of SDL as an obligation and requirement 


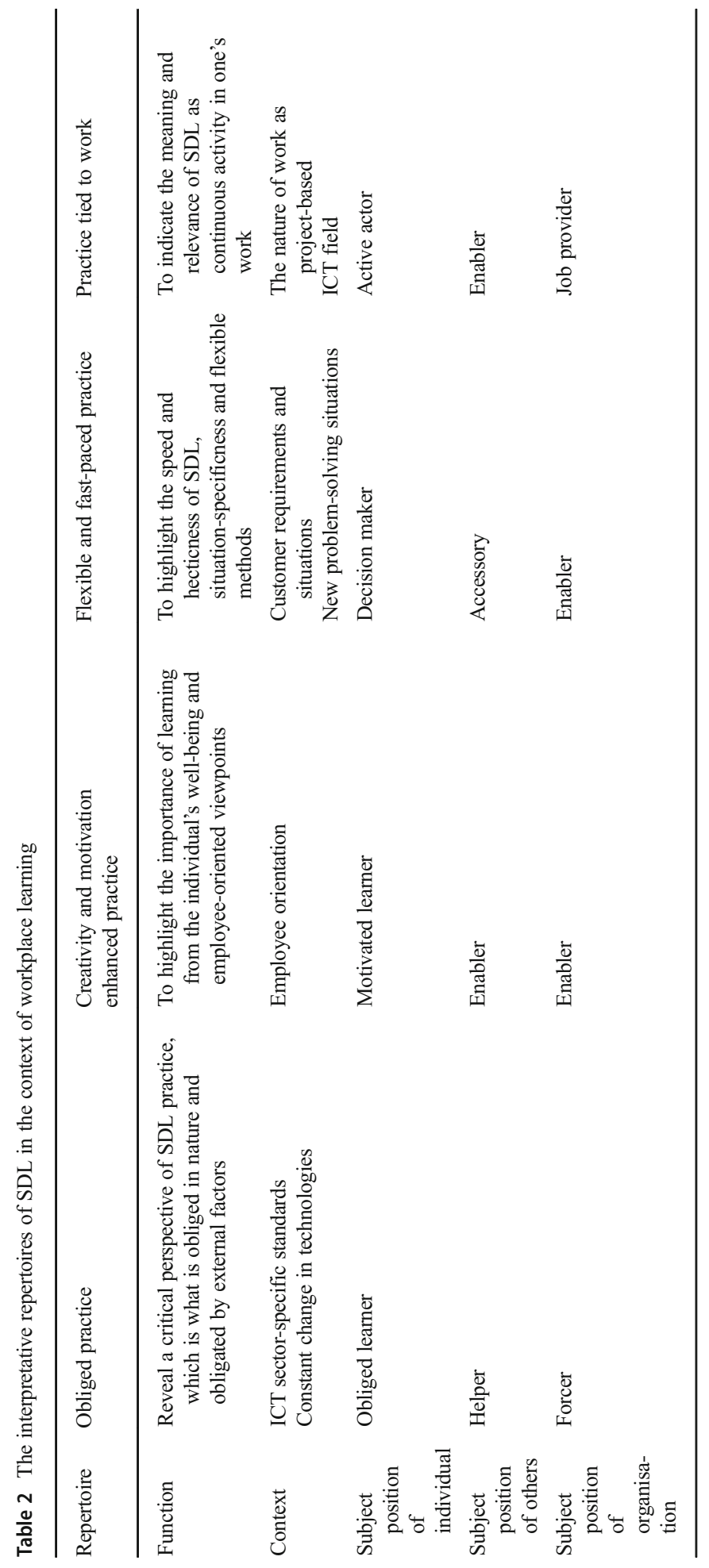


for work, even when they were not willing to learn. The next interview fragment shows that an employee sees SDL as an indispensable and obliged action for reasons beyond his control. This is particularly evident in the way in which learning and responsibility for learning from one's own learning is described as a problematic, non-motivating and timeconsuming practice and is not something the employee wants to implement in his own time. At the same time the environment (e.g., organisation and ICT sector), however, requires it:

Software developer (9): Because I don't want to work at home, after I started the job, my home coding is over, because 8 hours a day is enough for me. I didn't have any longer a motivation to do at home and now when it came to the obligation (from the organisation) to spend 24 hours a year working outside of working hours; it was quite a bit miserable for me because it is out of my other hobbies, and I have a lot of hobbies.

Interviewer: But do you do any work-related study outside of working hours? So you deliberately learn nothing at home, learn anything new?

Software developer (9): No, I don't, and it has been a problem for years when the technologies are going to develop all the time, but when I have another life there at home, and so I have told many times to my supervisors that I don't want to do work-related things in my own time. [xxx]. But the problem is that you fall by the wayside. In spite of that, I'm not doing it at home, except now that came the duty, I have learned that new system in my own time. [xxx]. But there are those people who do a lot of things with their free time and then share that knowledge with others at work.

In this interpretative repertoire, the context and reasoning for the speech could be the constant development of technologies and vocational field-specific obligations, which the personnel viewed as the reason for compulsory SDL. As is apparent from the previous data fragment, employees position themselves as obliged learners in this repertoire. The realisation of SDL was not described as being generated by the free will of the individual but rather externally. Employees talk about 'finding time for themselves', 'finding the right moments to learn' and, for example, 'look[ing] for solutions to relieve learning pressures'. The speech reflects the role of employees as learning respondents as challenging. The obligation of SDL was not limited to working time, as can be seen from the interviews above, but learning was also expected to take place during leisure time. The role of the organisation was seen as a forcer of SDL. In concrete terms, this could be seen in the speech of the Organisation A's employees, which prompted the organisation to require employees to spend $24 \mathrm{~h}$ per year of free time on independent learning. However, forcing SDL could be interpreted as including the phenomena described within working hours; the development of technologies requires continuous learning, but the employer does not offer extra time or opportunities to do, instead expecting that the employees themselves 'try to find solutions'. In this interpretative repertoire, speech about the individual and his or her learning strain were generally found, but some references to colleagues were also found. Colleagues were described in the repertoire as helpers in learning. Workers who have the time and opportunities to develop themselves outside working hours and want to share 
their new learning with other members of the work community were seen as helpers. This was seen as reducing the speakers' own commitment to learn in their leisure time while also allowing new information to be shared with colleagues.

\section{Creativity and Motivation Enhanced Practice}

SDL in the context of workplace learning was considered a meaningful aspect from the viewpoint of one's creativity and enthusiasm. SDL was described as tool for creativity, which is essential in ICT work. In addition to creativity, learning was described and talked about as a trigger for motivation. In this interpretative repertoire, SDL was described using phrases such as 'one gets to learn' and 'one gets to challenge', making it seem like a very positive phenomenon. Regarding the function of the speech, the need to highlight the importance and positive effects of learning was promoted. SDL was described as central, specifically in terms of the joy of work: 'New technologies and matters keep coming all the time, so you get to learn. If you did the same thing over and over again or worked with the same product, it would be pretty boring' (Software developer, Organisation A). The following data fragment shows that the individual's desire and motivation to learn and deeply understand the case (in this case the code) promote the creative process:

Software developer (15): That you get to learn new things is the one motivator here; the second motivator is to develop your own skills, which also brings new things. [xxx]. The company level has also been positively surprised by the fact that when there is a small company, it is able to take care of the employees a little differently. [xxx]. They are able to take the members of the company more individually into consideration.

Interviewer: We talked that you have a many of different skills, so how have they come about?

Software developer (15): In this job, Google is your friend and YouTube videos, and you get that information from online. Many people in this field just find a ready example (from the Internet) and copy it into the code. It's bad because if you just take some code and don't know how it works (it just works), it doesn't help learning or the creative process.

Creativity and enthusiasm, described as the outcomes of SDL, were presented as increasing an employees' sense of freedom and autonomy at work and their own learning, thus forming the broader context of the speech as having an employee orientation. The contextual interpretation was confirmed by how the employees position the organisation in this repertoire: the organisation was described as an actor that enables creative activity, for example, by taking workers as individuals, giving sufficient freedom and autonomy to do the work and otherwise working in employee-oriented ways. In this repertoire, one could observe in the interviewees' speech that they positioned themselves as motivated learners in terms of both creativity and enthusiasm. SDL was described as pleasant and as something that increases knowledge, creativity and enthusiasm. Even in this interpretation repertoire, there was not much talk about 
other employees or the team. The individuals focused on describing their own activities and personal goals for the learning and developing competency. It was possible to detect other positions of the actors by interpreting those mentioned in the speech, such as, 'I really want to develop over the next five years to such a level that I will say if not now the best of the company, but at least in the top ten of the company in terms of expertise' (Software developer 10), where colleagues are described mainly as benchmarks, as a mirror of their own level of expertise and thereby supporting the setting of development goals.

\section{Flexible and Fast-Paced Practice}

The practice of SDL was also said to be flexible and fast-paced. Flexibility in this repertoire illustrates that an SDL practice could include many different learning activities utilised by employees in a situational and flexible way. In terms of learning methods, it became essential when and where each method was used. The situations were often described as requiring a quick reaction and fast learning from the employees. The context of the learning speech was either customer orientation and/or problem-solving situations, which triggered the need for fast-paced and flexible SDL. The customer's needs should be addressed as quickly as possible, allowing the employee to make independent decisions about what is needed to learn and how the new understanding is achieved. Thus, the employee's subject position became a decision maker. Customer and problem-based situations were also often described as team wide, where the practice of SDL was manifested collectively: the team meets quickly to address a common problem and through discussion and shared views tries to form a solution. In this case, an accessory was formed as a subject position of the others. An example of the practice of SDL, which appears as a fast-paced form, is seen in the following fragment:

Interviewer: Are there any opportunities for learning, here, at work?

Software developer (8): The most obvious opportunity is that if a customer comes up with a request that 'we would like this feature in this system', then you start to think either alone or with a group, that if it is possible to do it at all, then you may need to check things using Google and see if anyone else has done it before. And usually, there is a blog or something similar that somebody has done, you read it, and take the things that you can apply or use, and this is how the knowledge and competence are accumulating.

Interviewer: And do you feel that within the working hours you are able to follow the blogs and read and know the information, get to know things?

Software developer (8): Well, it really varies a lot, so how busy you are with your job, [xxx] but usually, I can at least make a quick check of something. [xxx]. At least if somebody else suggests that you should read this or that, then I read it.

The fragments attached to the interpretative repertoire repeated the descriptions of 'haste', 'customer requirements', and listing various methods and their utility in relation 
to the problem or customer's need. The organisation was described as an enabler of learning in the repertoire. Enabling in this context means, for example, that the organisation has different electronic communication channels available to employees, whereby common problem solving is possible, even if the employees are not physically at the same place. In addition, it was interpreted as meaning that work planning was carried out within the organisation so that employees would have 'even a moment' to learn new things in all problem-solving situations. The function of speech was the need to highlight the speed and hecticness of SDL, situation-specificness and flexible methods.

\section{Practice Tied to Work itself}

The fourth interpretative repertoire was found in speech, where work was described as continuous SDL. Learning was thus considered an intrinsic and inextricable part of work; it was described as neither a negative nor positive phenomenon, but rather as neutral, selfevident and automatic. The function of the speech was to describe the significance and relevance of SDL, particularly in ICT work. The context of the speech was the nature of the work as project-based and IT field. The work was described as, for example, problem solving in which learning is embedded and where it was not necessary to 'separately practice' learning because it occurred naturally during everyday work. The following fragment shows how employees described their work as continuous SDL:

Software developer, project leader (22): Whenever a new thing comes in, you have to study yourself, and of course, you can get some information from your colleagues, but the possibilities of such an employer are really limited. [xxx]. How would I describe the software work, you have to read a lot of codes of other software and understand why it was made and how it was made and what practices it has used and then in some way adapted to it, to the particular environment.

Interviewer: So you're going to change the project, will it force you to learn new?

Software developer, project leader (22): Yes, yes. Self-development is present every day. It is actually my job. I mean, self-development is kind of intrinsic to the work. $[\mathrm{xxx}]$. It is really hard to me to see that it would be something separate, you are going somewhere and learning because it is intrinsic. [xxx]. 3\% of learning is about attending some courses, and $97 \%$ of it is like learning every day.

In this interpretative repertoire, the interviewed personnel described their roles in the learning as minor. Learning was seen as part of everyday work, indicating one must be very active when working. In this interpretative repertoire, the active actor became the subject position of the individual. Instead, the employer's support possibilities were described as limited, whereby the position of the organisation was only a work provider who cannot prevent or promote SDL but only create a framework for doing the job. Colleagues were described as enablers, who acted as a resource in work situations when an employee has a task that he or she cannot contribute to. 


\section{Discussion}

In the current study, we investigated how employees of ICT organisations describe the practice of SDL in the context of workplace learning. We found four different interpretative repertoires of SDL practice, in which contexts, functions and individual positions in relation to the self and others, as well as to the organisation, varied. The ICT workers talked about SDL as an obliged practice, creativity-enhanced practice, fast-paced and flexible practice and one tied to work itself. SDL practice was constructed as both, a phenomenon and activity individuals or teams should take responsibility for, and the processes where individuals or teams play an active role.

In line with previous studies, workplace learning (in which context SDL was considered in this study) was described as strongly intertwined with work practices themselves (Billett 2001; Collin 2006; Gherardi 2009). Workplace learning necessarily occurred during working and problem solving (Collin et al. 2018; Havnes and Smeby 2014; Nerland 2008), rather than taking place outside of work, such as with training and courses. Interestingly, unlike in most of the recent studies in the area of workplace learning, individuality in learning was emphasised in the employees' speech. This may have been detrimental in encouraging workplace learning, interaction and collaborative learning (Billett 2001; Brown and Duguid 2001; Gherardi 2006).

Interestingly, so far, the scarce empirical research has indicated self-directedness and SDL to be self-evident aspects (Moe et al. 2008) of contemporary agile and low hierarcy companies (Holbeche 2015). However, despite the increasing importance of SDL in ICT work (Ha 2008; Milligan et al. 2015; Germain and Grenier 2015), our findings indicate that learning should not become totally self-driven, as is the aim in some contemporary low-hierarchy, self-organising enterprises (cf. Lee and Edmondson 2017). Based on the principles of low-hierarchy organisations and SDL, the freedom and autonomy of learning, as well as the responsibility for learning, appear to be thrusted onto individuals. From this perspective, learning can be perceived as problematic and stressful if an employee cannot monitor and constrain his or her learning or if an employer does not provide the requisite opportunities, support and tools for monitoring learning. According to previous studies (e.g., Collin et al. 2018), employees may experience being left alone and abandoned if there is no support provided by the organizations. In this way, our findings can shed light on a more critical understanding of SDL. All employees may not see SDL only as a positive practice. On the contrary, it can also be felt as a burden and stressful obligation.

Self-directed learning was also constructed as a very positive image, where the nature of SDL practice was emphasised as creativity enhanced. In this speech, learning was approached as a possibility more than as a responsibility. The individual was positioned as a motivated learner. This dominant type of speech supports previous research that found a positive relationship between learning and creativity, as well as between creativity and professional agency (cf. Collin et al. 2018; Paloniemi and Collin 2012). In our findings, learning appears to support the creation of technical innovations and creative processes. Unlike in the previous repertoire, self-directedness was not seen as a negative issue because it enabled the selection of various means for individual development, as well as for technical innovation.

In our study, learning is strongly framed by the context: the technical nature of the work and the constantly changing technologies and digitalisation. Also, customers' 
needs and hopes and the problem-based nature of ICT work (Ha 2015; Hirschmann and Mulder 2018) frames learning. As a result, (self-directed) learning was perceived as a natural part of work. SDL was emphasised also by the hectic and simultaneity nature of learning situations when individuals and teams need to respond quickly and flexibly to the situation. This was not described as positive or negative, but rather as a natural and work-related activity. However, the speed of learning raises the question of how sustainable (cf. Matthews 1999) such hectic learning is.

The practice of SDL was most often described as a responsibility of the individual, but also as a 'shared responsibility'. Perhaps the work in the ICT sector is the reason why the ideal form of SDL appears to be more individual than team based. Instead, an organisation was positioned as enabling actors, not taking responsibility or even supporting practices. Therefore, our findings provide insights into organisations preferring self-directedness at a larger scale: the autonomy of the individual employee is emphasised when self-directed action is also culturally produced in learning as well. The organisation's role appeared negatively only when SDL was talked about as an obligation. In other cases, the organisation's role was either positive or neutral. Instead, team or colleagues were always described positive, even when an individual was forced to be self-directed, he or she described teams as 'easing the learning pain', thus assisting learning. Interestingly, the emphasis on self-directedness in our analysis also indicates that self-directedness might become a generally accepted idea both among employees and in the working culture. If this occurs, an important question arises concerning how employee well-being and developmental opportunities will be addressed when work and learning are not as inspiring or when there is so much work that learning is impossible. To summarise our findings, learning is a very important part of ICT work. In this sector especially, the nature of learning has obviously transferred to merely SDL and thus also changed the need to supervise this kind of learning (Bauer et al. 2012).

Using a discourse analysis enabled us to investigate the multifaceted nature of SDL (cf. Pintrich 2004). The analysis produced four interpretative repertoires slightly different from each other but also partly overlapping. The instruments utilised in the analysis enabled us to make interpretations both on the individuals' and colleagues' and team's role for learning. Thus, we could better grasp the collegial nature of SDL as well. Additionally, individually produced positions also enabled interpretations related to an organisation's responsibility, role and meaning in the area of SDL. The 'context' instrument deepened the analysis in revealing the background trends behind the practice of SDL. Fortunately, we collected a large amount of interview data - which is uncommon in discourse studies from two organisational contexts by utilising researcher triangulation (Patton 2015) that also ensures credibility and confirmability of findings as criteria of trustworthiness in qualitative research (see e.g. Lincoln and Cuba 1985a, b; Shenton 2004). Despite the credibility of the findings, the discursive method may have resulted in a strong emphasis on the individual. Additionally, we did not strictly ask about collegial or collective learning, which might have had an impact on the findings or on our interpretations. It would have been possible to broaden our understanding of SDL by utilizing additional data, for example group discussions. In this way, it would have been possible to find repertoires that emphasize even more strongly the importance of the group to SDL. However, the individual emphasis on learning, found in this study, is interesting because it is not the dominant paradigm in the field of workplace learning research (cf. Manuti et al. 2015; Tynjälä 2008). Using a number of different tools for reviewing the interpretative 
repertoires allowed for a deeper understanding of SDL practice, also ensuring dependability of our interpretations (see e.g. Elo et al. 2014; Shenton). Thus, with the help of these tools, we could make interpretations about the practices of SDL in different areas, in what contexts they appear, what is the role of the individual and also the roles of others in each repertoire. To strengthen the trustworthiness of our findings, we have also drawn attention to detailed description of the data collection and analysis phases, presented data-based citations and examples in the text and in Appendix 1 that confirms the interpretations (cf. Lincoln and Cuba 1985b).

The purpose was not to compare the differences between participating organizations in this study, and we did not have suggestions of any significant differences regarding SDL in the organizations. This is probably because the participating organizations were very similar, they work in the same industry and their management hierarchy is similar. Regarding the transferability of the findings, we suggest that the findings can undoubtedly be applied to ICT work, in low-hierarchy, self-organising enterprises (cf. Lee and Edmondson 2017). It is also expected that the prevailing phenomena and challenges associated with ICT workers' learning (e.g., circumstances related to launching and maintaining low-hierarchy and selfmanaging organisations) will spread to other fields of working life (Lee and Edmondson 2017). Thus, in the future it would be useful to compare the nature of self-directed learning in different vocational fields and organizational structures.

To change the nature of work relationships and understand the experiences of individuals performing these kinds of work, especially from a learning point of view, further investigation is needed. One promising direction for further studies is examining the relationship between (self-directed) workplace learning and creativity. Earlier studies have shown that creativity can be supported by exercising professional agency and learning, but we do not know how these concepts are concretely interrelated. The nature of learning in ICT work is transforming into becoming more flexible, fast-paced (Harteis 2017) and self-directed (Ellinger 2004) because of the many changes in workplace organisation. Because of the hectic nature of learning, its sustainability should also be critically examined: in the ICT sector, employees' competencies are linked to the technologies used, which are changing rapidly and continuously; future learning needs are difficult to predict when the question arises as to whether learning now and in the future can be seen as sustainable. Indeed, future investigations should also determine what kinds of structures, cultures and practices enhance workplace learning, as well as how these practices could be led and supervised to ensure that all employees are motivated to engage in practice-based learning. Our research provided information on the roles of different actors in self-directed learning, but more research is needed on the socio-cultural nature of self-directed learning at work. In the field of SDL at work, further consideration should be given to the collective practices and nature of SDL on the level of teams and organisation.

Acknowledgements This work was supported by the Finnish Work Environment Fund (project number 117300). We would like to thank the target organisations and the participants who voluntarily spent their time with us.

Funding Information Open access funding provided by University of Jyväskylä (JYU).

\section{Compliance with Ethical Standards}

Conflict of Interest No potential conflict of interest is reported by the authors. 


\section{Appendix 1. Examples of the analysis and quotations of the interviews}

Sections describing the context are bolded.

Sections describing the subject position of individual are italicised.

Sections describing the subject position of others are underlined.

Sections describing the subject position of organisation are in grey.

\section{Example 1. 'SDL as obliged practice'}

Software developer (16): Well, this is the problem all the time that when those technologies run so hard, and then one should try to learn new things all the time $[\mathrm{xxx}]$, one should find some time to learn, know how to learn and what to learn, in a way. We are lagging behind where development goes.

Interviewer: How can you find that time for learning? How do you learn?

Software developer (16): I don't do these things outside my working life because I have the other hobbies also, but in working hours I have to try to get the moments to learn things, that I usually try to get some new technology into a new project to learn that way.

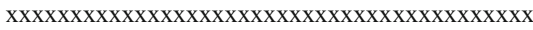

Software developer, project leader (23): The actual competence develops in practice through your own hobbies and learning at work, but when I try to find the rewards in this present situation (how and where to learn), my burden is my family situation. I can't use as much time for this adoption as I should, and it is out of the employer. [xxx]. Earlier, I have learned so that I have read and tried things $[\mathrm{xxx}]$, in the early 2000s, when I didn't have children, $I$ was able to use a lot of time to work and learning for work. [xxx]. The technologies are very short term in effect, which is why it takes quite a bit of time to keep up with that development.

\section{Example 2. 'SDL as a creativity and motivation enhanced practice'}

Software developer (11): Creativity is a personal feature, and personal features cannot be developed, but you can develop your competence and skills, which supports, are a prerequisite for creativity. I think that guitar is a good example of this: you have to learn to play the instrument, that you can make a creative guitar solo, you don't have to know at some level how to play. It is the same in 'code creativity', you need to have a certain level competence [so] that you can start thinking about the creative solutions or model.
Interviewer: Where does that certain level competence then form?

Software developer (11): So I practically got inspired when $I$ wanted to make web pages sometime in 2004, I studied myself and started working on scripts when no one else did them $\underline{\text { there, }}$ and I ended up here to do the code. I'm selfstudied, so practical it form by self-learning.

\section{Example 3. 'SDL as a flexible and faster-paced practice'}

IT expert (7): We are problem solvers, if we think about the job of our team it is based on customers' problem-solving situations. [xxx]. Many of these daily cases are not solved just by covering the instructions and doing and starting to work but by learning and expanding your knowledge. Even though we have some instructions that these are the most common support questions what comes, and the answers is here, but every day there are the exceptions that there is something wrong and then you have to think about it. You are going to ask help from your colleagues or team or try to find some information from the Internet - depending on the situation, you have to think about how to get the solution.

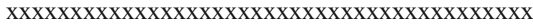

Software developer (13): We have a virtual chat channel for the team, that if somebody has a 
problem that one has to think about in a group, then you will be involved in that discussion, but that's when the problem comes.

Interviewer: But if you have a problem or someone else has a problem, how do you actually act with these chat channels?

Software developer (13): Everybody puts the handphones on the ear, then we make a division of the screen and everyone looks at the problem and thinks. [xxx].

Interviewer: Will they usually succeed if you get the problem now, then within five minutes, you will get your colleagues to a virtual meeting?

Software developer (13): Yes, it usually works if such a situation comes. At least within the same day. $[\mathrm{xxx}]$, But if I have a problem, then I first try to figure it out alone, [xxx].

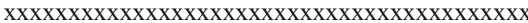

Interviewer: What is the meaning of learning in your work?

Software developer (17): [xxx]. I don't believe in those two-day trainings $[\mathrm{xxx}]$, some sort of real need should be, and then you start exploring how this works... so it is the way I learn best. [xxx]. Some problem-solving situation that now I need to find quickly what is the starting point, how to proceed and then go deeper and deeper. If any new technology comes up, it is a bit more challenging; then you have to find some advice on the Internet that you can learn how you could try to solve some problem.

Interviewer: How much of your work is learning?

Software developer (17): [xxx]. It depends of the need. If you need to do something new, then you study a lot of it and then get used to it. [ $\mathrm{xxx}]$.

Example 4. 'SDL as a practice tied to work itself'

Interviewer: What is the role of competence developing or workplace learning in your work?
IT Expert (4): Well, with all the time, it (competence) develops in this work and the fact that when you are interested in it you are always looking for new techniques to do better.

Open Access This article is distributed under the terms of the Creative Commons Attribution 4.0 International License (http://creativecommons.org/licenses/by/4.0/), which permits unrestricted use, distribution, and reproduction in any medium, provided you give appropriate credit to the original author(s) and the source, provide a link to the Creative Commons license, and indicate if changes were made.

\section{References}

Artis, A. B., \& Harris, E. G. (2007). Self-directed learning and sales force performance: An integrated framework. Journal of Personal Selling and Sales Management, 27(1), 9-24.

Bauer, H. G., Hemmer-Schanze, C., Munz, C., \& Wagner, J. (2012). Learning innovation work: Learning concept and framework. In F. Böhle, M. Bürgermeister, \& S. Borschen (Eds.), Innovation management by promoting the informal. Artistic, experience-based, playful (pp. 171-189). Dordrecht: Springer.

Billett, S. (2001). Learning through work: Workplace affordances and individual engagement. Journal of Workplace Learning, 13(5), 209-214. https://doi.org/10.1108/EUM0000000005548.

Billett, S. (2014). Mimesis: Learning through everyday activities and interactions at work. Human Resource Development Review, 13(4), 462-482.

Boud, D., \& Solomon, N. (2003). 'I don't think I am a learner': Acts of naming learners at work. Journal of Workplace Learning, 15(7/8), 326-331. https://doi.org/10.1108/13665620310504800.

Bourdieu, P. (1977). Outline of a theory of practice. Cambridge: Cambridge University Press.

Bourdieu, P. (1990). The logic of practice. Cambridge: Polity Press. 
Brockett, R. G., \& Hiemstra, R. (1991). Self-direction in adult learning: Perspectives on theory, research, and practice. London: Routledge.

Brookfield, S. (1986). Understanding and facilitating adult learning. San Francisco: Jossey Bass.

Brookfield, S. (1993). Self-directed learning, political clarity and the critical practice of adult education. Adult Education Quarterly, 43(4), 227-242.

Brown, J. S., \& Duguid, P. (2001). Knowledge and organization: A social-practice perspective. Organization Science, 12(2), 198-213. https://doi.org/10.1287/orsc.12.2.198.10116.

Burr, V. (1995). An introduction to social constructionism. London: Routledge.

Caffarella, R. S. (1993). Self-directed learning. New Directions for Adult and Continuing Education, 57, 2535 .

Candy, P. S. (1991). Self-direction for lifelong learning. San-Francisco: Jossey-Bass.

Cerasoli, C. P., Alliger, G. M., Donsbach, J. S., Mathieu, J. E., Tannenbaum, S. I., \& Orvis, K. A. (2018). Antecedents and outcomes of informal learning behaviors: A meta-analysis. Journal of Business and Psychology, 33(2), 203-230. https://doi.org/10.1007/s10869-017-9492-y.

Collin, K. (2006). Connecting work and learning - design engineers' learning at work. Journal of Workplace Learning, 18(7/8), 403-413. https://doi.org/10.1108/13665620610692971.

Collin, K., Herranen, S., Paloniemi, S., Auvinen, T., Riivari, E., Sintonen, T., \& Lemmetty, S. (2018). Leadership as an enabler of professional agency and creativity in information technology organisations. International Journal of Training and Development, 22(3), 222-232.

Davis, D., \& Daley, B. (2008). The learning organization and its dimensions as key factors in firms' performance. Human Resource Development International, 11(1), 51-66. https://doi.org/10.1080 $/ 13678860701782352$.

Edley, N. (2001). Analysing masculinity: Interpretative repertoires, ideological dilemmas and subject positions. In M. Wetherell, S. Taylor, \& S. J. Yates (Eds.), Discourse as data. A guide for analysis (pp. 89228). Milton Keynes: Open University.

Edwards, A. (2010). Being an expert professional practitioner: The relational turn in expertise. Dordrecht: Springer.

Ellinger, A. D. (2004). The concept of self-directed learning and its implications for human resource development. Advances in Developing Human Resources, 6(2), 158-177.

Elo, S., Kääriäinen, M., Kanste, O., Pölkki, T., Utriainen, K., \& Kyngäs, H. (2014). Qualitative content analysis: A focus on trustworthiness. SAGE Open, 4, 1-10.

Friedman, T. L. (2005). The world is flat. New York: Farrar, Straus, \& Giroux.

Fuller, A., \& Unwin, L. (2010). 'Knowledge workers' as the new apprentices: The influence of organisational autonomy, goals and values on the nurturing expertise. Vocations and Learning, 3(3), 203-222. https://doi.org/10.1007/s12186-010-9043-4.

Gerber, R., Lankshear, C., Larsson, S., \& Svensson, L. (1995). Self-directed learning in a work context. Education + Training, 37(8), 26-32. https://doi.org/10.1108/00400919510096952.

Gergen, K. J. (1999). An invitation to social construction. London: Sage.

Germain, M.-L., \& Grenier, R. S. (2015). Facilitating workplace learning and change. Journal of Workplace Learning, 27(5), 366-386. https://doi.org/10.1108/JWL-03-2013-0017.

Gherardi, S. (2000). Practice-based theorizing on learning and knowing in organization. Organization, 7(2), 211-223. https://doi.org/10.1177/135050840072001.

Gherardi, S. (2006). Organizational knowledge. The texture of workplace learning. Oxford: Blackwell.

Gherardi, S. (2009). Practice? It's a matter of taste! Management Learning, 40(5), 16. https://doi.org/10.1177 /1350507609340812.

Gijbels, D., Raemdonk, I., Vervecken, D., \& van Herck, J. (2012). Understanding work-related learning: The case of ICT workers. Journal of Workplace Learning, 24(6), 416-429.

$\mathrm{Gu}$, J. (2016). Understanding self-directed learning in the context of mobile web 2.0 - case study with workplace learners. Interactive Learning Environments, 24(2), 306-316.

Guglielmino, L. (2008). Why self-directed learning? International Journal of Self-Directed Learning, 5(1), 112.

Ha, T. S. (2008). How IT workers learn in the workplace. Studies in Continuing Education, 30(2), 129-143. https://doi.org/10.1080/01580370802097728.

Ha, T. S. (2015). Learning stories from IT workers - development of professional expertise. Studies in Continuing Education, 37(1), 79-98. https://doi.org/10.1080/0158037X.2014.967347.

Harteis, C. (2017). Machines, change and work: An educational view on the digitalization of work. In C. Harteis (Ed.), The impact of digitalization in the workplace. An educational view (pp. 1-12). Dotrecht: Springer. 
Havnes, A., \& Smeby, J.-C. (2014). Professional development and profession. In S. Billett, C. Harteis, \& H. Gruber (Eds.), International handbook of research in professional and practice-based learning (pp. 915986). Dordrecht: Springer.

Heinz, W. R. (2010). Vocational identity and flexible work: A contradicting or constructing relation? In F. Rauner, E. Smith, U. Hauschildt, \& H. Zelloth (Eds.), Innovative apprenticeships. Promoting successful school to work transitions (pp. 33-47). Berlin: LIT VERLAG.

Hirschmann, K., \& Mulder, R. H. (2018). Effects of complexity of work tasks on informal learning at work in the IT domain. In G. Teoksessa Messmann, M. Segers, \& F. Dochy (Eds.), Informal learning at work. Triggers, antecedents and consequences (pp. 40-62). Abingdon: Routledge.

Holbeche, L. (2015). The agile organization: How to build an innovative, sustainable and resilient business. London: Kogan Page.

Karakas, F., \& Manisaligil, A. (2012). Reorienting self-directed learning for the creative digital era. European Journal of Training and Development, 36(7), 712-731.

Khiat, H. (2017). Academic performance and the practice of self-directed learning: The adult student perspective. Journal of Further and Higher Education, 41(1), 44-59. https://doi.org/10.1080/0309877 X.2015.1062849.

Kirpal, S. (2009). Labour market flexibility, work orientations, and skills. In A comparative study of nurses and ICT technicians in Germany and UK. Dordrecht: Springer.

Knowles, M. (1975). Self-directed learning. Chicago: Follet.

Knowles, M., Holton, E. F., \& Swanson, R. A. (2012). The adult learner: The definitive classic in adult education and human resource development. London: Routledge.

Lee, M. Y., \& Edmondson, A. C. (2017). Self-managing organizations: Exploring the limits of lesshierarchical organizing. Research in Organizational Behavior, 37(1), 35-58. https://doi.org/10.1016/j. riob.2017.10.002.

Lee, Y.-J., \& Roth, W.-M. (2006). Learning about workplace learning and expertise from Jack. Journal of Workplace Learning, 18(4), 205-219. https://doi.org/10.1108/1366562061066581.

Lehner, F., \& Sundby, M. W. (2017). IT capabilities for SMEs: An analysis at the organisational level. In C. Harteis (Ed.), The impact of digitalization in the workplace. An educational view (pp. 125-140). Dotrech: Springer.

Lincoln, Y. S., \& Cuba, E. G. (1985a). Naturalistic inquiry. Beverly Hills: Sage.

Lincoln, Y. S., \& Cuba, E. G. (1985b). Naturalistic inquiry. Beverly Hills: Sage Publications.

Lindeman, E. (1926). The meaning of adult education. New York: New Republic Inc..

Loftus, S., \& Higgs, J. (2010). Researching the individual in workplace research. Journal of Education and Work, 23(4), 377-388. https://doi.org/10.1080/13639080.2010.495712.

London, M., \& Mone, E. M. (1999). Continuous learning. In E. D. Pulakos (Ed.), The changing nature of performance: Implication for staffing, motivation and development (pp. 119-153). San Francisco: JosseyBass.

Loyens, S., Magda, J., \& Rikers, R. (2008). Self-directed learning in problem-based learning and its relationship with self-regulated learning. Educational Psychology Review, 20, 411-427.

Maehl, W. H. L. (2000). Lifelong learning at its best. San Francisco: Jossey Bass.

Manuti, A., Pastore, S., Scardigno, A. F., \& Morciano, D. (2015). Formal and informal learning in the workplace: A research review. International Journal of Training and Development, 19(1), 1-17. https://doi.org/10.1111/ijtd.12044.

Martins, E. C., \& Terblanche, F. (2003). Building organizational culture that stimulates creativity and innovation. European Journal of Innovation Management, 6(1), 64-74.

Matthews, P. (1999). Workplace learning: Developing an holistic model. The Learning Organization, 6(1), 18-29. https://doi.org/10.1108/09696479910255684.

Merriam, S. (2001). Andragogy and self-directed learning: Pillars of adult learning theory. New Directions for Adult and Continuing Education, 89, 3-13.

Merriam, S., \& Caffarella, R. S. (1999). Learning in adulthood. San Francisco: Josey-Bass.

Milligan, C., Fontana, R. P., Littlejohn, A., \& Margaryan, A. (2015). Self-regulated learning behaviour in the finance industry. Journal of Workplace Learning, 27(5), 387-402. https://doi.org/10.1108/JWL-02-20140011.

Moe, N. B., Dingsoyr, T., \& Dypa, T. (2008). Understanding self-organizing teams in agile software development. Paper presented at 19th Australian Conference on Software Engineering (pp. 76-85). IEEE.

Nerland, M. (2008). Knowledge cultures and the shaping of work-based learning: The case of computer engineering. Vocations and Learning, 1(1), 49-69. https://doi.org/10.1007/s12186-007-9002-x.

Noe, R. A., \& Ellingson, J. E. (2017). Autonomous learning in the workplace. New York: Routledge. 
Noe, R. A., Clarke, A. D. M., \& Klein, H. J. (2014). Learning in the twenty-first-century workplace. Annual Review of Organizational Psychology and Organizational Behavior, 1(1), 245-275.

Nunan, D. (1993). Introducing discourse analysis. London: Benquin Group.

Nunan, D., \& Lamb, C. (1996). The self-directed teacher: Managing the learning process. Cambridge: Cambridge University Press.

Paloniemi, S. (2006). Experience, competence and workplace learning. Journal of Workplace Learning, 18(7/8), 439-450. https://doi.org/10.1108/13665620610693006.

Paloniemi, S., \& Collin, K. (2012). Discursive power and creativity in inter-professional work. Vocations and Learning, 5(1), 23-40.

Patton, M. (2015). Qualitative research \& evaluation methods integrating theory and practice (5th. ed.). London: Sage.

Pintrich, P. R. (2004). A conceptual frame work for assessing motivation and self-regulated learning in college students. Educational Psychology Review, 16(4), 385-407.

Potter, J., \& Wetherell, M. (1987). Discourse and social psychology: Beyond attitudes and behavior. London: Sage.

Rana, S., Ardichvili, A., \& Polesello, D. (2016). Promoting self-directed learning in a learning organization. European Journal of Training and Development, 40(7), 470-489.

Riddell, S., Ahlgren, L., \& Weedon, E. (2009). Equity and lifelong learning: Lessons from workplace learning in Scottish SMEs. International Journal of Lifelong Education, 28(6), 777-795. https://doi.org/10.1080 /02601370903293252.

Rigby, C. S., \& Ryan, R. M. (2018). Self-determination theory in human resource development: New directions and practical consideration. Advances of Developing Human Resources, 20(2), 133-147. https://doi.org/10.1177/1523422318756954.

Salovaara, P., \& Bathurst, R. (2018). Power-with leadership practices: An unfinished business. Leadership. https://doi.org/10.1177/1742715016652932.

Scheeres, H., Solomon, N., Boud, D., \& Rooney, D. (2010). When is it OK to learn at work? The learning work of organisational practices. Journal of Workplace Learning, 22(1/2), 13-26. https://doi.org/10.1108 $/ 13665621011012825$.

Schürmann, E., \& Beausaert, S. (2016). What are drivers for informal learning? European Journal of Training and Development, 40(3), 130-154.

Shenton, A. K. (2004). Strategies for ensuring trustworthiness in qualitative research projects. Education for Information, 22(2), 63-75.

Silverman, D. (1997). Discourses of counselling. HIV counselling as social interaction. London: Sage.

Soreide, G. E. (2016). High-skilled newcomers' identity: Learners or experts? Journal of Workplace Learning, 28(1), 2-16. https://doi.org/10.1108/JWL-12-2014-0088.

Streumer, J., \& Björkvist, D. (1998). Moving beyond traditional vocational education and training: Emerging issues. In W. J. Nijhof \& J. N. Streumer (Eds.), Key qualifications in work and in education (pp. 249264). Dordrecht: Kluwer Academic Publishers.

Stubbs, M. (1983). Discourse analysis: The sociolinguistic analysis of natural language. Chicago: The University of Chicago Press.

Taylor, S. (2001). Locating and conducting discourse analytic research. In M. Wetherell, S. Taylor, \& S. J. Yates (Eds.), Discourse as data. A guide for analysis (pp. 5-48). Milton Keynes: Open University.

Though, A. (1971). The adults' learning projects. Toronto: The Ontario Institute for Studies in Education.

Tynjälä, P. (2008). Perspectives into learning at the workplace. Educational Research Review, 3(2), 130-154. https://doi.org/10.1016/j.edurev.2007.12.001.

Tynjälä, P. (2013). Toward a 3-P model of workplace learning: A literature review. Vocations and Learning, 6(1), 11-36. https://doi.org/10.1007/s12186-012-9091-z.

Ulrich, F., \& Mengiste, S. A. (2014). The challenges of creativity in software organizations. In B. BergvallKåreborn \& P. A. Nielsen (Eds.), Creating value for all through ITB (pp. 16-34). Dordrecht: Springer.

Vähäsantanen, K., \& Eteläpelto, A. (2017). Professional agency and learning in the work of software professionals. In C. Harteis (Ed.), Machines - change - work: An educational view on the digitalization of work (pp. 161-179). Dordrecht: Springer.

Valleala, U. M., Herranen, S., Collin, K., \& Paloniemi, S. (2015). Fostering learning opportunities through employee participation amid organizational change. Vocations and Learning, 8(1), 1-34.

Van Dijk, T. A. (1998). The study of discourse. In T. A. van Dijk (Ed.), Discourse as structure and process (pp. 1-34). London: Sage.

Vanthournout, G., Noyens, D., Gijbels, D., \& Van den Bossche, P. (2014). The relationship between workplace climate, motivation and learning approaches for knowledge workers. Vocations and Learning, 7(2), 191214. https://doi.org/10.1007/s12186-014-9112-1. 
Wetherell, M. (1998). Positioning and interpretative repertoire: Conversation analysis and post-structuralism in dialogue. Discourse and Society, 9(3), 387-412. https://doi.org/10.1177/0957926598009003005.

Wetherell, M., \& Potter, J. (1988). Discourse analysis and the identification of interpretative repertoires. In C. Antaki (Ed.), Analysing everyday explanation: A casebook of methods (pp. 168-183). London: Sage.

Yeo, R.K. (2008). How does learning (not) take place in problem-based learning activities in workplace contexts. Human Resource Development International 11(3), 317-330

Wetherell, M., \& Potter, J. (1992). Mapping the language of racism. Discourse and the legitimation of exploitation. New York: Harvester Wheatsheaf.

Publisher's Note Springer Nature remains neutral with regard to jurisdictional claims in published maps and institutional affiliations.

Soila Lemmetty, M.A. (education), is a Ph.D. student and project researcher at the Department of Education, University of Jyväskylä. Currently, her research interests are workplace learning, creativity at work and various leadership practices in work environments.

Kaija Collin is a university researcher and adjunct professor. She works at the Department of Education, University of Jyväskylä. Her research interests include workplace learning, professional identity and agency, interprofessional work practices, creativity, leadership and professional development in general and in various organisational contexts. Collin's work has been widely published internationally, and she has extensive experience supervising doctoral students. 